\title{
Islamic literature: definition, nature and scope
}

\author{
Md. Mahmudul Hassan \\ Centre for University Requirement Courses \\ International Islamic University Chittagong, Bangladesh
}

\begin{abstract}
Literature is a pellucid mirror that reflects the reality of life, society and the universe. It emanates from ideas, emotions, and beliefs of individual or collective personality irrespective of national, linguistic, cultural, religious and stylistic differences. Islamic literature deals with the features of all aspects of Islam. It is not confined in person, group or nation as well as place or time, but represents a clear appeal for the whole humanity forever. The paper aims at studying the definition of Islamic literature and then sheds light on identifying the nature and scope of this literature.
\end{abstract}

Keywords Pellucid mirror, Collective personality and a clear appeal

Paper type Literature review

\section{Introduction}

Literature signifies all human activities and behaviors, either in verbal or physical form. It is of attractive arts which refreshes the minds and attracts the hearts. The human beings are fond of it from antiquity. It reflects on particular social, political as well as cultural aspects such as philosophy, art, sculpture, music and so on. It is at present times-generally taken to be imaginative compositions, mainly printed but earlier was oral, whether dramatic, metrical or prose in form (Peter Childs \& Roger Fowler, 2006:129). Islamic literature has an important role in propagation of Islamic doctrine. It goes to build a strong and incomparable horizon equipped with various colors of Islamic ideology, education, ethics and history along with traditional background.

\section{Definition of literature}

Etymologically, literature has to do with letters, the written as opposed to the spoken word, though not everything that is written down is literature. According

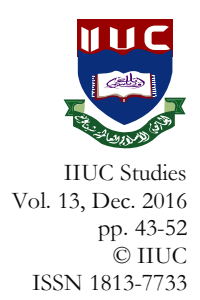




\section{IIUC STUDIES, 13}

to the Oxford Advance Learner's Dictionary, the word 'literature' means "pieces of writing that are valued as works of art, especially novels, plays and poems" (Hornby, 2004:751). In Arabic language, 'adab' (أدب) is the synonym word of literature which refers to prescribed etiquette, refinement, good manners, morals, decorum, decency, humaneness, 'norm of conduct' and custom (Jacob E. Safra, 2006:10), knowledge, politeness, and education (Newby, 2004:18). Since the 19th century, the broader sense of literature as a totality of written or printed works has given way to more exclusive definitions based on criteria of imaginative, creative, or artistic value, usually related to a work's absence of factual or practical reference as poetry, drama, and fiction (Jaun. E. Campo, 2009: 10). Until the mid-20 th century, many kinds of non-fictional writing - in philosophy, history, biography, topography, science and politics - were counted as literature (Chris Baldick, 2001:142). The renowned writer Sayyed Qutub defined literature as:

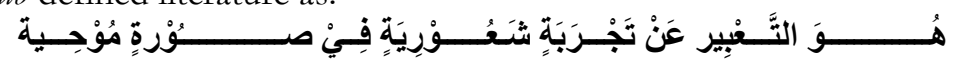

"It is an expression of emotional experience in inspiring method."(Sayyed Qutub, 1990:9).

The prominent litterateur D. Muhammad al- Tunji described literature as:

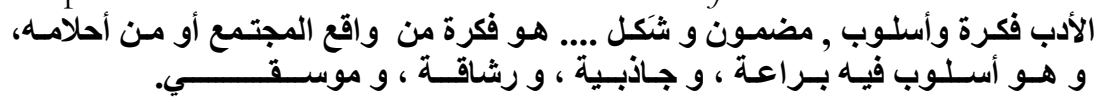

"Literature is an impression and style, registered and illustration. It is an impression of the reality of society or of its dreams. It includes style with stillness, attraction, elegance and music" (al-Tunji, 1993:48).

The illustrious lexicographer Chris Baldick defined literature as: 'Literature' is a body of works related by subject- matter by language or place of origin or by prevailing cultural standards of merit. It also includes oral, dramatic, and broadcast compositions that may not have been published in written form but which have been preserved" (Chris Baldick, 2001:141).

The common definition of literature covers the major genres of poetry, drama, novel and fiction. The term also implies literary quality and distinction. In present times - letters, diaries, reports, petitions, journals and essays as well as the traditional genres of novel, short story, poem and play etc are included in literature.

\section{Definition of Islamic literature}

The term "Islamic literature" consists of two fundamental components, 'Islamic' and 'literature'. In Arabic language, the synonym of Islamic literature is al-Adab al-Islami (الأدب الإسلامي). The term 'Islamic' is used for 
those instances where there is a conscious effort to reflect the fundamental principles and ideals of Islam interpreted in a relatively restrictive way. As Islamic literature is a combing form of two words; Islam and literature, so the literature that includes the ideology and ethics which Islam wants to establish and spread to the nation is called Islamic literature. The views of famous Islamic writers on Islamic literature are as follows:

a. Imad al-Din Khalil said: "It is an aesthetic impressive expression in words of the Islamic concept of existence". (al- Khalil Imad al-Din, 1987:69).

b. The modern Islamic author Muhammad Qutub said:

إنه التـعبير الجميل عن حقائق الوجود، من زاوية التصور الإسلامي لهذا الوجود" "Indeed, it is a beautiful expression of the reality of existence in the angle of Islamic notion for this existence. (Muhammad Qutub, 1400 H., 119).

c. The Islamic scholar Abu Saleh Abdul Quddus said:

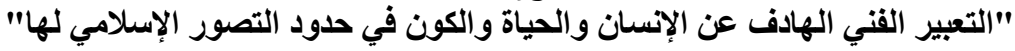
"The meaningful artistic expression of humankind, life and the universe within the framework of Islamic notion."(Abdul Quddus, 1410 H, 86).

d. Abd al- Rabmān Ra'fat Bāshā said:

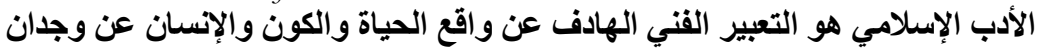

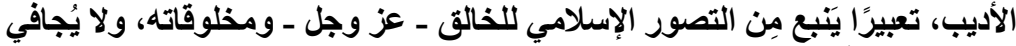

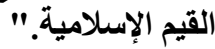

"Islamic literature is an artistic meaningful expression about the reality of life, the universe and humankind by the conscience of litterateur with an expression stemming from the Islamic perception of the Creator- the Almighty- and His creatures, and it does not turn away from Islamic values"(al- Bāshā, 1985:113).

e. The famous Islamic author Ibtisam Marbun al-Saffar said:

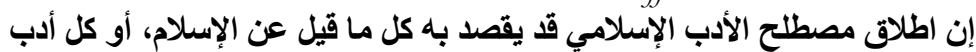

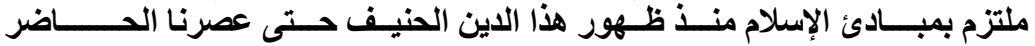

"Indeed, the term 'Islamic literature' is used for denoting what is said about Islam or all literatures committed by the fundamentals of Islam from the advent of this True Religion till our present Age."(Al-Saffar, 2005:10).

f. The renowned Islamic litterateur D. Najïb al-Kilani demonstrated Islamic literature as: 


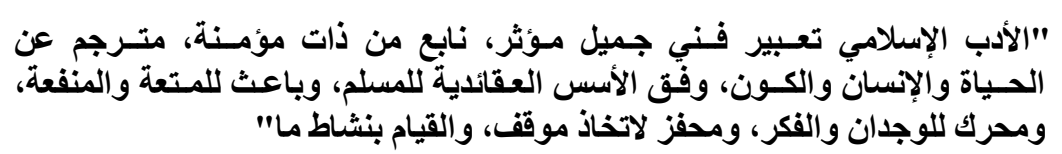

"Islamic literature is an influential beautiful expression emanated from a faithful personality, an interpreter for human, life and the universe in accordance with the principles of Islam, motivator of pleasure and benefit, activator of emotion and thought, and the stimulator to take a position and to embark on certain activities." ( $\mathrm{Al}$ Kilani, 1407 H, P-36).

g. Famous Islamic scholar Abdullah said that Islamic literature must ensure two conditions:

First, it has to be a beautiful expression of life, man and the universe. Secondly; the expression must conform to Islamic teachings and principles. (Abdullah, Y. 2008:14-27)

The summary of the above opinions of famous litterateurs on the definition of Islamic literature are in the following pinpoints:

$\checkmark$ An artistic meaningful expression.

$\checkmark$ The expression stemming from the Islamic perception of the Creator- the Almighty- and His creatures.

$\checkmark$ The expression must conform to Islamic teachings and principles.

$\checkmark$ The expression does not turn away from Islamic values.

$\checkmark$ It emanates from a faithful personality.

$\checkmark \quad$ It is an interpreter for human, life and the universe in accordance with the principles of Islam.

$\checkmark$ It is a motivator of pleasure and benefit.

$\checkmark \quad$ It is an activator of emotion and thought.

In a nutshell, Islamic literature is the literature written in Islamic perspective in any language. It usually deals with the history of Islam, Islamic legends, and the stories of the personalities mentioned in the Qur'an and the Traditions of the Prophet Muhammad (PBUH). It springs into existence from the world-view of a Muslim, adaptable to all times and all ages.

\section{The nature of Islamic literature}

Nature is the inherited characteristics of a thing or a person that distinguishes itself from others. Islamic literature is illustrious with its own 
nature. According to the statements of the eminent litterateurs, we can pinpoint the nature of Islamic literature with the following features:

a. Islamic literature is indissolubly linked to Islamic belief (al-Kilani, 1987:5) that encompasses all inclusive movements of existence. So, it must be independent of any other ideology or influence apart from Islam (Barigish, 1985:38). Rather in Islamic literature, man, life and the universe are seen through the telescope of Islam (al- Nadawi, 1985:29). It presents itself as an important medium of Allah's message to the mankind (al-Guri, 2000:27).

b. Islamic literature emanates from an Islamic personality. A writing resembling Islamic literature compiled by a non- Islamic writer is not considered a genre of Islamic literature, rather it may be called أدب

- the literature of normal instinct or الأدب الفطرة السوية the the neutral literature or الأدب المو افت للإسبلام- the corresponding literature in Islam (Quassab, 1998:35). For instance, if we peruse the literature of pre- Islamic era, we get more Islamic ideogical aspects which Islam deals with- such as, belief in Allah, remembrance of death, grave and al-Akhirah (the Hereafter), the truth, discarding the habit of falsification, contentment in achievement, fulfilling the promise and fearing Allah, warning of the evil things and characteristics as wrongdoing, envy, vulgar imagination and avarice, bad aftermath of the disobedience of the parents, importance of good behavior with neighbors and guests etc. which are highlighted in Islam. Specially, there were several literary figures who distinguished themselves as moral persons and dealt with moral things in their literary works. The prominent figures among them were Hashim ibn 'Abd Manäf, 'Abd alMuttalib, Zubayr, Quss ibn Saidah al-Iyadi, al-Harith ibn' Abbad al-Bakeri and Labid bin Rabiyah. (Al-Zayyat, 2000:18-35).

c. Islamic literature conforms to the line demarcated by Islamic thinking and gives a clear identication of the subject matter, description and expression (al-Shanti, 2010:30). The form and content of Islamic literature must be complementary to one another and must be of a high standard because neither the form alone nor the content without the other can make a literary work effective to achieve its prime objective. (Barigish, 1985:40).

d. Islamic literature deals with all the different affairs of life; the positive and negative affairs of men and women, the various issues of the nations, and all problems of the whole humanity in a polite manner (alMakki, 1994:3). It protests all kinds of oppression such as oppression of the rich on the poor, the strong upon the weak, the owner upon the laborer, the white upon the black etc. (al-Nadawi, 1985:19). 
e. Islamic literature has aims and objectives. The objective is making the faith in Allah (SWT) and firmly established it in peoples' hearts, making good values deeply rooted in their minds and to ignite in them the potential power of doing good and righteousness (al-Guri, 2000:27). The mission of Islamic literature is promoting Islamic values and good education for the generation. It does not encompass any type of chit-chat, filth, and libido (al-Kilani, 1987:56-58).

f. Islamic literature may be from any country, any place and any Islamic personality which reflects on Islamic perspectives (Qassab, 1998:31). It has no specific language rather it is open to all languages of the world. It has no specific time or era, rather it may be in any time or era. (Tahir, 2000:13-15).

g. All genres of literature- poetry, prose, epic, novel, drama, and memoirs etc. reflected by Islam are regarded as Islamic literature. There are numerous writings of Islamic literature in Arabic language unlike other languages though it can be emanated from all existing languages in the world. For example, we can cite here some outstanding literary works of modern period of Arabic literature that bring forward the nature of Islamic literature. A remarkable Islamic poem in modern period is alHamziyyah al- Nabawyyah الهمزية النبوية written by Ahmad Shawqī that deals with the panegyric of the Prophet Muhammad (PBUH) in a lucid versification. Another remarkable Islamic poem is اللؤلؤ المكنون (alLu'lu' al-Maknūn - the preserved pearls) versified by poet Mohammad Manla Ghrayel. Risalab fi Lailah al- Tanfidh (رسالة في ليلة التنفيذ - a message on the night of execution) written by Häshem al-Refa ‘, Yaquilu Lanà al-Shabid (يقول لنا الثهيد - the martyr tells us) written by'Ahmad Fahr 'Aqlān, Nihàyah (نهاية -an end) written by Muhammad 'Awad, Fi al- Qudus Qad Nataqa al Hajar (في القدس قد نطق الحجر - the stone spoke in Jerusalem ) written by Khalid Abu al- 'Umrain, Risālah Tla Khaled bin Walid @ رسالة إلى خالد بن الوليد- رضي الله عنه - a message to Khalid bin al-Walid ) written by D. 'Abd al- Rahmān al-'Ashmawī, Alladhina Jāwō bi al-Ifk (الذين جاءوا بالإفلك - those who brought forward the fabrication) written by Muhammad Rajab al-Biwamī and so on are of Islamic poetry conveying the nature of Islamic literature. There are ample Islamic Diwans (ديوان الشعرالإسلامي -collections of Islamic poems) composed in the nature of Islamic literature. A remarkable work of this arena in modern period is Nuqöshun Islamiyyatun 'Ala al- Hajar alFlistini (نقوش إسلامية على الحجر الفلسطيني - Islamic inscriptions on the Palestinian stone) written by Mahmud Mufleh..Jisr 'ala Nabr Drinā - a bridge on the river Drina )written by Hasan alAmrāni, and so on are outstanding works in this field. Epic is a lengthy narrative poem in artistic style containing details of heroic deeds and events (al Tunji,1993:824). A few Islamic epics (الملحمة الإسلامية) are available in Arabic literature that put up with the nature of Islamic 
literature. The epic titled Malhamat al-Nabi-Sallallabu 'Alaibi wa Sallam written by 'Umar Abu Rīshah, is an excellent exemple in this field where the poet discoursed on the major event of the Prophet Muhammad (PBUH) in a splendid versification. Al- Ilyadhatu alIslamiyyatu (الإلياذة الإسلامية - Islamic Iliad) written by Ahmad Muharram, and Ma'sat al-Tarikh (مأساة التاريخ) the tragedy of history) written 'Abd al- Rahman 'Ashmawi and so on are noteworthy works in this field. There are copious examples of Islamic prose (النزر الإسلامي) literature; short story, novel, drama, memoirs are in modern period of Arabic literature. Bayt al- 'Ankaboot (بيث العنكبوت-the spider's house) written by Hannan Lahham is an excellent short story where the writer discussed social affairs in Islamic perspective through the quotation of Qur'anic verses. Noor al-Mehraab (نور المحراب - the light of mihrab) written by Yusuf al- 'Adhm., Rijaal Allah ( رجابل الله الهُ - the men of Allah) written by Najib al-Kilaani., Al-Yaqdbtu (اليقظة - the awakening) written by Muslim Maimum, Hädithatu fi Shari'i al- Hurriyyah ( حادثة في - an incident in the way of liberation) written by Ibrahim 'Asi etc are remarkable literary works in this area. A lot of Islamic novels are available in Arabic literature. Nör Allah (الله - the light of Allah) written by Najib al-Kilaani is a classic Islamic novel that narrates the fighting between Islam and anti- Islamic organization as the Jews and hypocrites in the beginning of Islamic preaching. This novel presents the bad behavior, betrayal, breaking agreement of the Jews with the Prophet Muhammad (PBUH) and their successive attempts to assassinate him instead of his mercy to them. The novel wound up by narrating the conquest of Makkah and the entering of disbelievers to Islam in crowds. Qätilu Hamzah قاتل حمزة) - the assassin of Hamza ${ }^{\circledR}$, and Riblatu ila Allah (رحلة إلى الله) - a journey to Allah) written by Najib al-Kilānī etc are outstanding works of Arabic Islamic novel. A few Islamic dramas are available in Arabic literature. Abl al-Kahaf (أهل الكهف - the people of the cave") written by Tawfiq al Hakim is a notable Islamic drama which narrates the Qur'anic story of cave dwellers in excellent style. Al- Ma'suroon المأسورون) - the captives) written by 'Imad al - Din Khalil, Bulbul al- Islam (بلبل الإسلام) the nightingale of Islam) , Al-Silsilah wa al-Gufraan (السلسلّة والغفران) the chain of sin and forgiveness), Haroot wa Maroot (هاروت و ماروت)( and al- Da'wat al- Mustajabat (الدعوة المستجابة) - the accepted supplication) written by 'Ali Ahmad Baaksir are outstanding samples of Arabic Islamic drama. A genre in Islamic literature is memoirs added in modern period of Arabic literature. Al- Tareeq ila al-Islam (الطريق إلى الإسلام) - the way to Islam) written by Muhammad Asad, Ayyam Min Hayaati (أيام من حياتي - days from my life), written by Zaynab al- Gazzaali. Riblati Ma'a al-Adab al- Islami” رحلتي مع الأدبان (الإسلامي -my trip with Islamic literature) written by Najib al- Kilani and so on are notable Islamic memoirs that convey the nature of Islamic literature. In a word, the Holy Qur'an and the Prophetic 


\section{IIUC STUDIES, 13}

Traditions are two main sources and excellent models of Islamic literature in all ages. The orations, epistles, speeches and poems of His companions are also valuable literary treasury of Islamic literature. And all genres of literature formed in Islamic framework are of Islamic literature.

\section{The scope of Islamic literature}

Islamic literature is not confined in person, group or nation as well as place or time. It is built for world wide appeal. It gives a clear appeal for the whole humanity. It is an excellent model of literature for any country or age ('Abd al-Däim, 2002:41). It includes all kinds of feelings of joy and sorrow, satisfaction and indignation, anger and kindness, weeping and smiling, liking and disliking, serious and banter, misery and pleasure, mind and conscience, wisdom and play. It describes the behavior of a friend with a friend, represents the man's behavior with women, and draws the emotion of humankind in their activities and feelings, influence in all influences, and their response for each visible phenomenon of attention. It deals with history and biography, story and epistle, speech and conversation, description and drawing, and beautiful influential expression. It is a fluent prose, a marvelous poetry, and a vivid image of literary style. It is bashing and reproach, exultation and enjoyment, statement and making understand. It is a literal mirror of human life in all its cosmic circumstances; nevertheless, it escapes from all filths and corruptions (al- Nadawi, 1985:21).

Islamic literature has no specific form and style rather it contains various forms of the present style of literature along with Islamic norm and perspective such as poetry, drama, novel, short story, composition, prose poem, travel story, and biography etc. and various artistic styles such as lyrical trend, realistic trend, idealistic trend, romantic trend, classical trend, mystic trend and symbolic trend etc.

The area of Islamic literature extends from western Africa to Malaysia, Indonesia, and the Philippines; but its heartland is Arabia, and the prime importance and special authority of the Arabic language was to remain largely unquestioned after the spread of Islam (Kathleen Kuiper, 2010:45). So, all literary works which contain Islamic norms will be counted as Islamic literature. Either it is in Arabic, English, Frence, Spanish, Russian, Bengali, Urdu or Hindi and so on. Though Islamic literature originated from Arabic literature because Arabic is the official language of Islam and the language of its main two sources- the Holy Qur'an and the Sunnab- is Arabic. And this language has become the lingua franca of the Muslims across the world, (al-Makki 1994:43), but then, Allah (SWT) has wisdom in creating different languages and sending each of His prophets with the language of the 
people. It is an undisputable fact that the Muslims, who are using their native language to conduct daily transactions, document their experience and express their religious ideas and feelings, are more than those who use Arabic for the same endeavors. These facts make the Islamic scholars conclude that Islamic literature could adopt any language as its medium of expression. The most important thing is for the content and the language of a literary work to conform to Islamic teachings and principles and must be beneficial to the Muslims and the human race as a whole. With this, the literature will have universal application and acceptability like the Islamic religion itself.

\section{Conclusion}

This paper has made an attempt to explore the definition of Islamic literature and it has been observed that literature is a human product. If it conforms to Islamic teachings and principles, it will be considered Islamic. Then, the study has examined the nature and scope of Islamic literature and proved that it has no boundary of language, race and territory. In the epilogue of the study, we can identify the following momentous pinpoints:

a. Islamic literature can be in any genre of literature- prose, poetry, prose poem, epic etc.

b. It emanates from human ideas, emotions, and behaviors.

c. Its expression must be in Islamic framework.

d. It aims at preaching the message of the Creator Allah (SW'T) to His Creatures.

e. It can be in any existent language of the world.

f. It should be lucid and evocative.

\section{References}

'Abd al- Dāim, D. S. (2002). Al-Adab al-Islamī baina al-Ndhriyyah wa al-Tatbíq. AlQahira: Dar al- Surūq. 5(9).

Abdullah, Y. (2008). Masāilu al-Adabī al-Islamī al-Mu'āsir. Ilorin Journal of the Humanities,

Al- Bāshā, A. R. (1985). Nabwa Madhabin Islamiyyin fi al-Adab Wa al-Naqd. Riyadh: Imam Muhammad Saud Islamic University.

Al- Saffar, I. M. (2006). Al- Amāni fi al-Adab al- Islami. Oman: Dar al- Manahij.

Al- Shanti, D. M. S. (2010), fi al-Adab al- Islamī (4th ed.). K.S.A: Dar al- Andalus. 


\section{IIUC STUDIES, 13}

Al- Tunjī, D. M. (1993). Al-Mu'jam al- Mufassal fi al-Adab (1 ${ }^{\text {st }}$ ed.). Beirut: Dar alKutub al 'Ilmiyyah.

Al-Guri, A. M. (2000). Allamtu Abul Hasan Alì al- Hasañ al- Nadwì wa Nažātubu wa Ta'amulätubu wa Jubüdubu fi al-Adab al-Islami. Beirut: Dar ibn kathir.

Al-Khalīl, Imad al-Dīn. (1987). Madkhal ila Nazariyyat al-Adab al- Islamì. Beirut: Dar al Risalah.

Al-Kilanī, D. N. (1407 H). Madkhal ilā al-Adab al-Islamī (1 ${ }^{\text {st }}$ ed.). Qatar.

Al-Kilanī, D. N. (1987). Al-Islamiyyah wa al- Madhähib al-Adabiyyah. Beirut: Muassasah al- Risalah.

Al-Makkī, T. A. (1994). Muqaddamah fi al- Adab al-Islamial-Muqärin. Egypt: Ein for Human and Social Studies.

Al-Nadawī, A. H. (1985). Al- Adab al- Islamì wa Silätubu bil Hayāti (1 ${ }^{\text {st }}$ ed.). Beirut: Muassasah al- Risalah.

Al-Zayyat, A. H. (2000). Tärikeh al- Adab al- 'Arabī (7th ed.). Beirut: Dar al Ma'rifah.

Barigish, M. H. (1985). Fi al- Adab al- Islamī al-Mu 'ásir. Jordan: Maktabah al-Manar.

Chris, B. (2001). The Concise Oxford Dictionary of Literary Terms. New York: Oxford University Press.

Hornby, A. S. (2004). Oxford Advanced Learner's Dictionary (6 ${ }^{\text {th }}$ ed.). UK: Oxford University Press.

Jacob, E. S. (2006). Britannica, Encyclopedia of World, Religion. Encyclopedia Britannica Inc.

Juan, E. C. (2009). Encyclopedia of Islam, New York: Facts on File.

Kathleen, K. (2010). Islamic art, literature, and culture. New York: Britannica Educational Publishing.

Newby, D. (2004). A Concise Encyclopedia of Islam. UK: One world Publications.

Peter, C., \& Roger, F. (2006). The Routledge Dictionary of Literary Terms. New York: Routledge.

Quassab, D. W. (1998). Fi al-Adab al-IslamīDar al Qalam. Dubai, UAE.

Quddus, A. S. A. $(1410$ H). Al-Adab Ma Huwa? Majallah al- Faisal, No-171, Ramadan.

Qutub, M. (1400 H.). Minhaj al- Fann al- Islamì (4th $e d$.$) . Beirut: Dar al - Shuruq.$

Qutub, S. (1990). Al- Naqd al-Adabi Usulubu wa Manähijubu (6 ${ }^{\text {th }}$ ed.). Beirut: Dar al - Shuruq.

Tahir, D. H. (2000). Al- Adab al-Islamī; Āafäq wa Namażj. Al Qahirah: Daru Qubaa.

\section{Corresponding author}

Md. Mahmudul Hassan can be contacted at: mahmudulhassan1184@yahoo.com 